\title{
Budd-Chiari Syndrome and Acute Liver Failure: An Uncommon Presentation of Acute Myeloid Leukaemia
}

\author{
Ana Rita Gonçalves Costa ${ }^{a}$ Inês Freitas ${ }^{b}$ Joana Raposo ${ }^{c}$ Gustavo Barbosa ${ }^{d}$ \\ Helena P. Miranda ${ }^{\mathrm{e}-\mathrm{g}}$ Filipe Nery ${ }^{\mathrm{d}, \mathrm{f}, \mathrm{g}}$ \\ a Serviço de Medicina Interna, Centro Hospitalar Universitário do Porto, Porto, Portugal; b Serviço de Hematologia \\ Laboratorial, Centro Hospitalar Universitário do Porto, Porto, Portugal; ' Serviço de Anatomia Patológica, Centro \\ Hospitalar Universitário do Porto, Porto, Portugal; ' ${ }^{d}$ Serviço de Cuidados Intensivos, Centro Hospitalar Universitário \\ do Porto, Porto, Portugal; ' Unidade de Transplante Hepato-pancreático, Centro Hospitalar Universitário do \\ Porto, Porto, Portugal; ${ }^{f}$ Instituto de Ciências Biomédicas de Abel Salazar, Universidade do Porto, Porto, Portugal; \\ gEpiUnit - Instituto de Saúde Pública da Universidade do Porto, Porto, Portugal
}

\section{Keywords}

Acute liver failure $\cdot$ Budd-Chiari syndrome $\cdot$ Acute myeloid leukaemia

\section{Abstract}

Acute liver failure (ALF) is a rare entity, particularly in the context of Budd-Chiari syndrome (BCS). BCS is an uncommon disorder with multiple risk factors, most commonly myeloproliferative disorders. In BCS, active search and exclusion of underlying malignancy is mandatory, particularly in the context of ALF, as it may contraindicate liver transplantation (LT). We present the case of a healthy 29 -year-old male, without known risk factors for liver disease, who presented to the emergency department with abdominal pain, ascites, and jaundice. BCS with consequent severe acute liver injury with rapid progression to ALF was diagnosed. The patient was listed for LT. The study of peripheral blood finally revealed myeloid blasts, and flow cytometry showed a population of blast cells with abnormal immunophenotypic profile (CD33+ and myeloperoxidase, MPO+). The bone marrow biopsy showed morphological and immunophenotypic aspects of acute myeloid leukaemia (AML) FAB M1. This diagnosis was considered a formal contraindication to LT, so the patient was delisted. ALF contraindicated rescue chemotherapy and AML contraindicated LT. The patient died $48 \mathrm{~h}$ after ICU admission. The search for underlying neoplasia is mandatory in the context of BCS, moreover with associated ALF, as it may limit lifesaving treatments and interventions to supportive and palliative care.

(c) 2020 Sociedade Portuguesa de Gastrenterologia Published by S. Karger AG, Basel

Síndrome de Budd-Chiari e Falência Hepática Aguda: Uma Apresentação Incomum de Leucemia Mieloide Aguda

\section{Palavras Chave}

Falência Hepática aguda · Síndrome Budd-Chiari . Leucemia mieloide aguda

\section{Resumo}

A falência hepática aguda (FHA) é uma entidade rara, particularmente no contexto da Síndrome de Budd-Chiari
This article is licensed under the Creative Commons AttributionNonCommercial-NoDerivatives 4.0 International License (CC BYNC-ND) (http://www.karger.com/Services/OpenAccessLicense) Usage and distribution for commercial purposes as well as any distribution of modified material requires written permission.
Ana Rita Gonçalves Costa

Serviço de Medicina Interna, Centro Hospitalar Universitário do Porto Largo do Prof. Abel Salazar

PT-4099-001 Porto (Portugal)

arcosta89@gmail.com 
(SBC). A SBC é uma doença incomum com múltiplos fatores de risco, principalmente as doenças mieloproliferativas. Na SBC, a procura ativa e exclusão de malignidade subjacente é obrigatória, particularmente no contexto de FHA, já que pode contraindicar o transplante hepático (TH). Apresentamos o caso de um homem de 29 anos saudável, sem fatores de risco conhecidos para doença hepática que se apresentou no serviço de urgência com dor abdominal, ascite e icterícia. A SBC associada a lesão hepática severa com rápida progressão para FHA foi diagnosticada e o doente colocado em lista para TH. O estudo do sangue periférico finalmente revelou a presença de blastos mieloides e a citometria de fluxo a presença de uma população de blastos com perfil imunofenotípico anormal (CD33 + e mieloperoxidase (MPO) +). A biópsia da medula óssea mostrou aspetos morfológicos e imunofenotípicos de leucemia mieloide aguda (LMA) FAB M1. Este diagnóstico foi considerado uma contraindicação formal para o $\mathrm{TH}$, pelo que o doente foi retirado de lista. Pela FHA a quimioterapia de resgate estava também contraindicada. 0 doente faleceu 48 horas após a admissão na $\mathrm{UCl}$. O despiste de neoplasia subjacente é obrigatório no contexto de SBC, ainda mais com FHA, pois pode limitar o tratamento lifesaving a cuidados de suporte e paliativos.

(C) 2020 Sociedade Portuguesa de Gastrenterologia Published by S. Karger AG, Basel

\section{Introduction}

Acute liver failure (ALF) is a rare syndrome, representing $8 \%$ of all liver transplants in Europe [1]. Multiple conditions may evolve to ALF, and establishing aetiology has prognostic and therapeutic importance [2]. Budd-Chiari syndrome (BCS) is a rare disease, with the recent estimates of incidence and prevalence widely varying depending on the studies [3]. In Europe, BCS prevalence is estimated at 1.4-2 per million inhabitants $[4,5]$ and, particularly in France, the incidence is estimated at 2.17 per million habitants, reflecting the rarity of this syndrome [3]. BCS refers to the obstruction of hepatic veins or the terminal inferior vena cava, and has a wide spectrum of presentation, from asymptomatic to ALF [6]. ALF is, however, a rare complication [7]. In Western countries, multiple risk factors have been identified, from the intake of oral contraceptives, underlying prothrombotic conditions, and, most commonly, myeloproliferative disorders, with most of the patients having more than one risk factor [3, 6]. Darwish Murad et al. [8] identified the presence of one risk factor in $84 \%$ of the patients and two or more risk factors in $46 \%$. Besides myeloproliferative disorders, which are commonly associated with BCS [3], other haematological neoplasms are quite rare and only published as case reports [9-11]. As malignancy is a formal and absolute contraindication for liver transplantation (LT) in the acute setting, its exclusion in the workup diagnosis of ALF is mandatory [2].

\section{Case Report}

A 29-year-old previously healthy male presented to the emergency department with fatigue, jaundice, and epigastric and right upper quadrant abdominal pain with a 4-day duration. He denied nausea, vomiting, fever, malaise, anorexia, choluria, or acholia. The patient was haemodynamically stable, without fever. On physical examination, the patient was oriented, icteric, without flapping, with a distended and tender abdomen, with grade 2 ascites, and a palpable as well as painful liver. Complete blood count revealed anaemia (haemoglobin of $8.6 \mathrm{~g} / \mathrm{dL}$ ), with anisocytosis; leucocytosis $(11,000 \mu \mathrm{L})$ with lymphocytosis $(10,610 \mu \mathrm{L})$, and thrombocytopenia $(<10,000 \mu \mathrm{L})$. Marked elevations of liver enzymes [AST 118 times the upper limit of normal (ULN); ALT 172 times ULN], hyperbilirubinemia $(2.8 \mathrm{~g} / \mathrm{dL})$, acute kidney injury (creatinine of $1.7 \mathrm{mg} / \mathrm{dL})$, and lactacidaemia $(8 \mathrm{mmol} / \mathrm{L})$ as well as coagulopathy with an INR of 4.7 were noted. Severe acute liver injury was diagnosed based on the presence of coagulopathy in the absence of hepatic encephalopathy (HE). By then, the patient was admitted to the Intermediate Care Unit. The workup diagnosis excluded infection with acute hepatotropic viruses, autoimmune diseases, and Wilson disease. Abdominal Doppler ultrasound revealed hepatomegaly with a heterogeneous structure and low volume ascites as well as documented alterations in hepatic venous flow (no sure individualization of suprahepatic veins [SHVs]) with a filiform aspect of the inferior vena cava. Portal vein was patent with hepatofugal flow. The abdominal CT scan confirmed absence of flow at SHVs, and the diagnosis of BCS was established. Paracentesis revealed a serum/ascites albumin gradient $(\mathrm{SAAG})>1.1 \mathrm{~g} /$ $\mathrm{dL}$, and spontaneous bacterial peritonitis was ruled out. No anticoagulation treatment was immediately started due to severe thrombocytopenia and coagulation disorders. General supportive measures were initiated. The patient evolved with development of grade 2 West-Haven HE and severe coagulopathy (INR 4.76; FV $3.5 \%)$. By that time, and 4 days after initial hospital admission, the patient was transferred to the intensive care unit (ICU), and listed for urgent LT. Repeated complete blood count revealed the presence of an increased number of myeloid blasts. A population of blast cells with abnormal immunophenotypic profile (CD33+ and myeloperoxidase, $\mathrm{MPO}+$ ) was found in peripheral blood flow cytometry. Bone marrow biopsy was performed, and the morphological study revealed densely cellular medullary spaces, occupied by a population of medium-sized blast cells (Fig. 1). Immunohistochemical study demonstrated myeloid differentiation, with immunoreactivity to MPO (Fig. 2), CD68 (KP1 and PGM1 clones), $\mathrm{CD} 15$, and CD117. Therefore, the diagnosis of acute myeloid leukaemia FAB M1 was established. By this time, the patient was delisted due to the haematological malignancy and initiation of rescue chemotherapy was not possible due to liver failure. Symptomatic 
Fig. 1. Bone marrow biopsy showing (a) densely packed medullary spaces occupied by sheets of medium-sized blasts (H\&E, $40 \times)$. The inset (b) illustrates this population in greater detail $(\mathrm{H} \& \mathrm{E}, 400 \times)$.

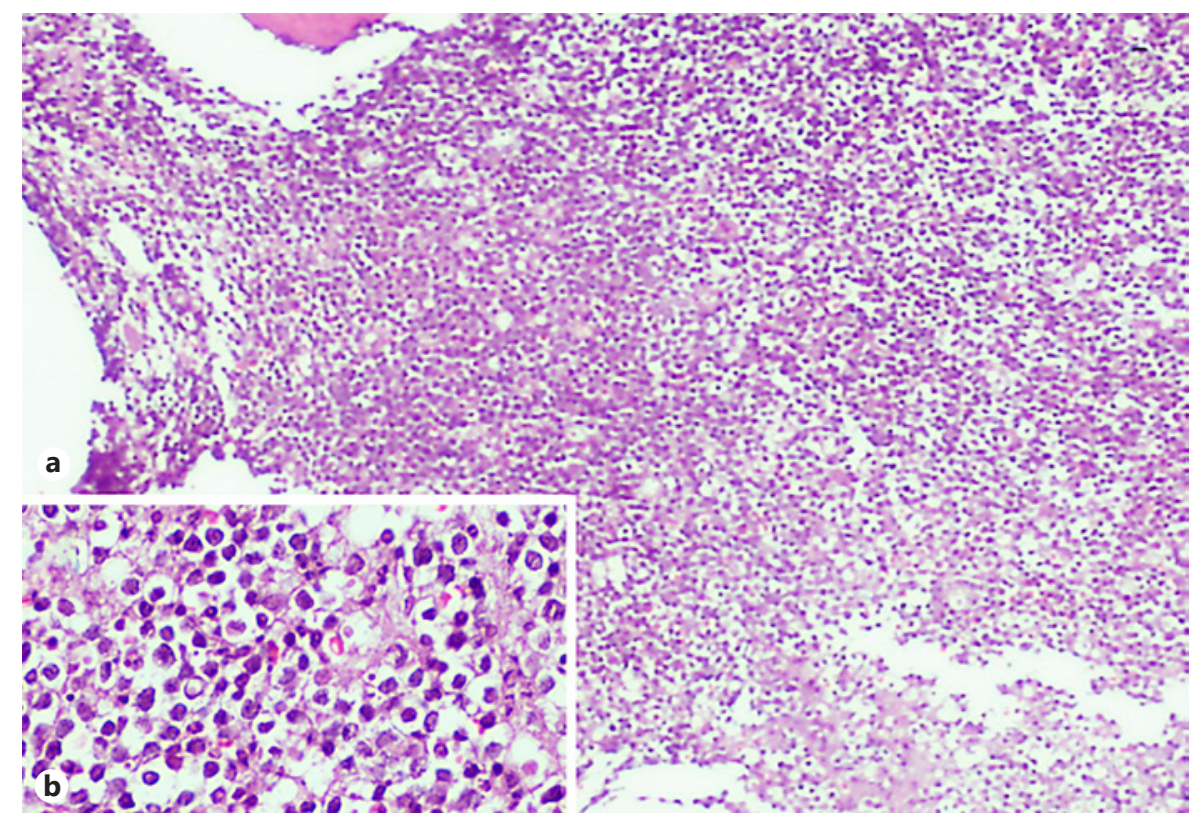

treatment was proposed. The patient died $48 \mathrm{~h}$ after admission in the ICU. The rapid progression to death is multifactorial in origin, due to multiorgan failure combined to palliative symptomatic treatment. Post-mortem liver biopsy confirmed the diagnosis of BCS, with concomitant extra-medullary haematopoiesis. No leukaemia cells were found in the liver biopsy (Fig. 3).

\section{Discussion}

Patients with cancer have a derangement of the haemostatic system, increasing the risk of both haemorrhagic and thrombotic complications, particularly venous thromboembolism (VTE). This association is well described for solid tumours [12]. Although haemorrhagic complications were previously thought to be the most frequent complications of haematological malignancies, it is now known that these patients have a risk of VTE similar to the one described in patients with solid tumours, and in this particular population thrombotic events can be underestimated [12]. The episode of VTE can either precede the diagnosis or be the presenting event of the haematological malignancy [12].

Myeloproliferative disorders are the most frequent haematological neoplasms associated with BCS and are diagnosed in $30-50 \%$ of cases. Other haematological neoplasms are rarely associated to BCS $[3,6,8]$, and, to our knowledge, there are only 3 reported cases with simultaneous hepatic vein thrombosis and AML as initial presen-

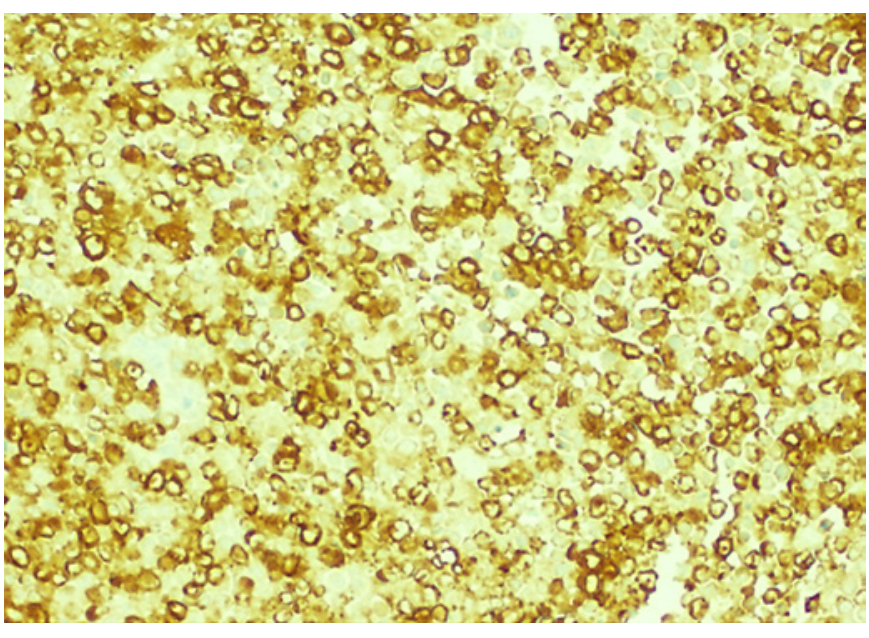

Fig. 2. The blast population shows frequent MPO expression, which demonstrates the myeloid differentiation (MPO, 200×).

tation [9-11]. All these cases are related to acute promyelocytic leukaemia, which is known to turn patients more susceptible to thrombosis besides bleeding disorders [13]. Our patient did not present with a M3, but rather M1 (acute myeloblastic leukaemia with minimal maturation) form of AML, which has never been associated to BCS before.

In the context of ALF, particularly if there is an indication for LT, an active search for malignant infiltration of the liver and active neoplasia is mandatory. This is of par-
64

GE Port J Gastroenterol 2021;28:62-66 DOI: $10.1159 / 000507335$
Costa/Freitas/Raposo/Barbosa/Miranda/ Nery 
Fig. 3. a The morphological study of the liver biopsy shows sinusoidal dilatation, atrophy of the trabecula, and areas of hepatocytes necrosis: these features are compatible with BCS (H\&E, 100×). b Simultaneously, there is morphological evidence of extramedullary haematopoiesis, with easily identifiable megakaryocytes (H\&E, 400×), and it was also demonstrated with immunohistochemical study to glycophorin that stains erythroid blasts (glycophorin, 400×) (c) and CD61 that stains megakaryocytes $(\mathrm{CD} 61,400 \times)(\mathbf{b})$.

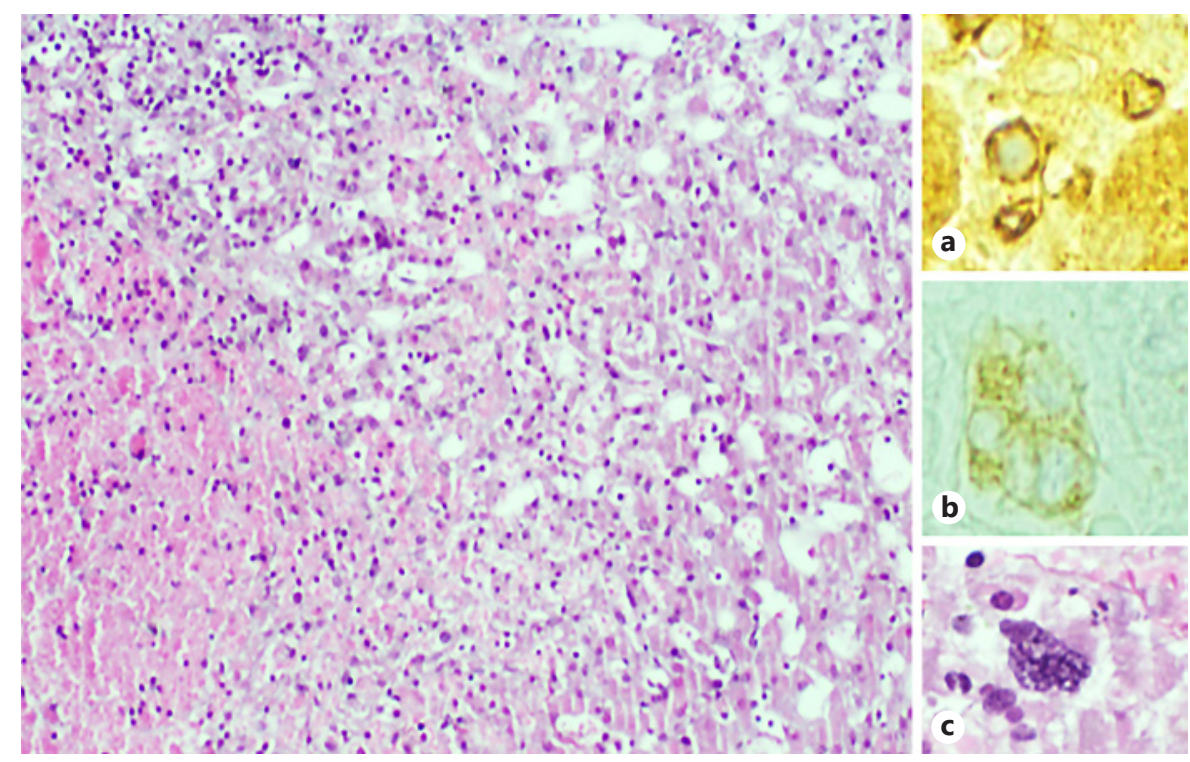

ticular importance in the context of acute BCS, since malignancies, namely haematological, are frequently associated $[2,3,6,14]$. In this particular case, the patient rapidly evolved from severe acute liver injury to ALF with the rapid onset of HE, motivating urgent LT referral. The active search for an aetiology justifying the aforementioned haematological abnormalities (severe thrombocytopenia and lymphocytosis) which could not be affiliated with the liver condition, led to prompt investigation of active neoplasia, which would contraindicate the LT.

With the present case, the authors wanted to underline: (i) the pro-thrombotic state associated with acute leukaemia, not usually associated; (ii) that severe thrombocytopenia did not protect from the thrombotic event; (iii) that acute thrombosis could, by means of platelet consumption, have some contribution to the severity of thrombocytopenia; and (iv) that a prompt search for active malignancy is mandatory in the context of ALF irrespectively of the aetiology, particularly when related to BCS. In this case, thrombosis of the SHVs was rather a consequence of a pro-thrombotic state in the context of acute leukaemia than the result of local factors associated with liver invasion by leukemic cells, as no infiltration was seen in the liver biopsy specimen. Yet, liver extramedullary haematopoiesis shall be considered as a local important factor in the genesis of a thrombotic event. This case clearly demonstrates the association of three rare entities: BCS, AML, and ALF altogether in which the treatment of one condition contraindicates the treatment of the other.

Budd-Chiari Syndrome and Acute Myeloid Leukaemia

\section{Acknowledgments}

Thanks to the medical team of the Intensive Care Unit of the Centro Hospitalar Universitário do Porto.

\section{Statement of Ethics}

The patient's written consent was not obtained because the patient died within a short period of time, so it was not possible. The description of the case does not allow (implicit or explicit) the identification of the patient.

\section{Disclosure Statement}

All authors of this paper have no possible conflicts of interest to disclose and no other nonfinancial relationships that may influence the writing of the manuscript.

\section{Funding Sources}

The authors received no funding for the current case report.

\section{Author Contributions}

All authors have been implicated either in the diagnosis and/or clinical management of the patient. A.R.C. and F.N. were responsible for the draft of the article and provided critical revision of the manuscript for important intellectual content. J.R. reviewed the histology images and helped with choice and legend. All authors revised the manuscript for final version approval. 


\section{References}

1 Mendizabal M, Silva MO. Liver transplantation in acute liver failure: A challenging scenario. World J Gastroenterol. 2016 Jan;22(4): 1523-31.

2 Wendon J, Cordoba J, Dhawan A, Larsen FS, Manns M, Samuel D, et al.; EASL Governing Board representative. EASL Clinical Practical Guidelines on the management of acute (fulminant) liver failure. J Hepatol. 2017 May; 66(5):1047-81.

3 Ollivier-Hourmand I, Allaire M, Goutte N, Morello R, Chagneau-Derrode C, Goria O, et al. The epidemiology of Budd-Chiari syndrome in France. Digestive and Liver Disease. 2018 Apr; 50(9): 931-7. https://doi. org/10.1016/j.dld.2018.04.004.

4 Rajani R, Melin T, Bjornsson E, Broome U, Sangfelt P, Danielsson A, et al. Budd-Chiari syndrome in Sweden: epidemiology, clinical characteristics and survival - an 18-year experience. Liver Int. 2009 Feb;29(2):253-9.
5 Ageno W, Dentali F, Pomero F, Fenoglio L, Squizzato A, Pagani G, et al. Incidence rates and case fatality rates of portal vein thrombosis and Budd-Chiari Syndrome. Thromb Haemost. 2017 Apr;117(4):794-800.

6 European Association for the Study of the Liver. Electronic address: easloffice@easloffice.eu. EASL Clinical Practice Guidelines: vascular diseases of the liver. J Hepatol. 2016 Jan;64(1):179-202.

7 Parekh J, Matei VM, Canas-Coto A, Friedman D, Lee WM; Acute Liver Failure Study Group. Budd-chiari syndrome causing acute liver failure: A multicenter case series. Liver Transpl. 2017 Feb;23(2):135-42.

8 Darwish Murad S, Plessier A, HernandezGuerra M, Fabris F, Eapen CE, Bahr MJ, et al.; EN-Vie (European Network for Vascular Disorders of the Liver). Etiology, management, and outcome of the Budd-Chiari syndrome. Ann Intern Med. 2009 Aug;151(3):167-75.
9 Bandyopadhyay S, Bandyopadhyay D. Acute Budd-Chiari syndrome as an initial presentation of acute promyelocytic leukemia. J Cancer Res Ther. 2010 Oct-Dec;6(4):567-9.

10 Riccio JA, Colley AT, Cera PJ. Hepatic vein thrombosis (Budd-Chiari syndrome) in the microgranular variant of acute promyelocytic leukemia. Am J Clin Pathol. 1989 Sep;92(3): 366-71.

11 Chillar RK, Paladugu RR. Case report: hepatic vein thrombosis (acute Budd-Chiari syndrome) in acute leukemia. Am J Med Sci. 1981 Nov-Dec;282(3):153-6.

12 Falanga A, Marchetti M. Venous thromboembolism in the hematologic malignancies. J Clin Oncol. 2009 Oct;27(29):4848-57.

13 Chang H, Kuo MC, Shih LY, Wu JH, Lin TL, Dunn P, et al. Acute promyelocytic leukemiaassociated thrombosis. Acta Haematol. 2013; 130(1):1-6.

14 European Association for the Study of the Liver. Electronic address: easloffice@easloffice.eu. EASL Clinical Practice Guidelines: liver transplantation. J Hepatol. 2016 Feb;64(2): $433-85$. 